\title{
A Review Paper on
}

\section{"U-Boot Beton: The Concrete Saver"}

\author{
Shoeb Khan Taslim Khan (B.E. Student) \\ Email: shoebtaslimkhan@gmail.com \\ DOI: 10.29322/IJSRP.10.07.2020.p10383 \\ http://dx.doi.org/10.29322/IJSRP.10.07.2020.p10383
}

Department of Civil Engineering, Babasaheb Naik College Engineering, Pusad, Maharashtra India

\begin{abstract}
U-Boot technology is capable of supporting large without beams. U-Boot beton is a farm work made of recycled polypropylene. Voids from work placed in between the top in bottom reinforcements of slab. It is used to create slabs with large span or that are able to support large load without beams. U-boot is fire resistance. It is a recycled polypropylene formwork that was designed to create lightened slab \& rafts. U-boot systems can be combined with other technologies pre-fabricated with other techniques such as post tensioned steel and pre-fabricated slabs. The technology of hollow slab with part tensioned steel. It reduces the weight of slab \& its thickness.
\end{abstract}

Keywords: U-boot Foot/Needles, spacer, joint, fire resistance, low cost material

\section{INTRODUCTION}

$\mathrm{U}$ Boot is a technology that reduced the amount of concrete required. U-boot technology comes to 2001 when Robert-II Grande, an Italian engineer, developed and patented a new system of hollow former to reduce transport vehicles .It is the recycled polypropylene formwork technology used for construction purposes. One of the important barrier with constructions, in instance of horizontal slabs is the soaring weight, which ceiling the span.

It creates lighter economical design for structure. For this reason major developments of reinforcement concrete have focused on enhancing the span. This is used to construct two way slab, large span slab, and mushroom slab and raft foundation in RCC structure. It is suitable for high rise building, hospitals and parking management Residential and industrial buildings. In u-boot automation, slabs are fabricated with large span a contract floor thinner by depleting the weight while keeping the advance of reinforced concrete technology.

\section{OBJECTIVES}

The U-Boot technology is very useful technology for building construction. The main objective is to reduce the dead load of slab and reduced the overall cost of slab. The U-Boot reduce the amount of concrete required. This is especially important for environmentally green and sustainable.

\section{HISTORY AND BACKGROUND}

U-boot technology comes to 2001 when Robert-II Grande, an Italian engineer, Developed and patented a new system of hollow former to reduce transport vehicles. This is a new technology that has been in operation since 2002 .

\section{TYPES OF U-BETON}

- Single U-Beton

- Double U-Beton

Single U-Beton is available of various up beton height and foot height of dimension $(52 \mathrm{~cm} * 52 \mathrm{~cm})$ And 10, 13,16,20,24 And $28 \mathrm{~cm}$ in Height.

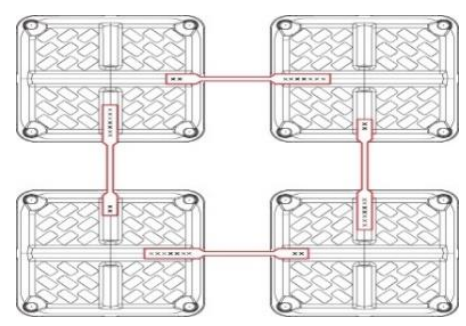

\section{MATERIAL USED}

Cement, Steel, Fine aggregate, Course aggregate, Water, Recycled plastic mould (u-boot Shells) 


\section{SCOPE}

This technique will also be used later. As population increases, its demand will also increase as we will need large and economic house in future. It can be used in public as well as residential buildings.

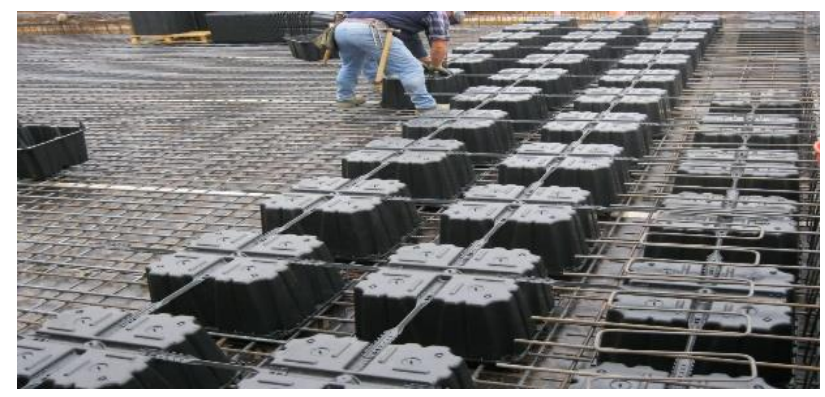

\section{INSTALLATION PROCESS}

1. Place lower reinforcement above the formwork.

2. Now place the U-Boot above the lower reinforcement at the specified intervals provided by the horizontal link connectors.

3. Now complete the upper reinforcement which above the U-Beton.

4. Now Pouring of concrete is being done.

5. Now concrete is poured and slab is ready.

\section{ADVANTAGES}

- $\quad$ By using U-Boot technology when can increased number of floors.

- By using U-Boot beton we can get large span.

- Using the U-Boot does not place any beam between the poles.

- Therefore there is a decrease in the number of pillars.

- The weight on the poles and foundation results in a decrease in the overall weight of the structure.

- Due to U-Boot Beton reduced foundations - less deep foundation excavation.

- U-Boot technology improved acoustic behaviour.

- By reducing the number of poles, the economic pillars is increased

- Thickness of the slab is reduced

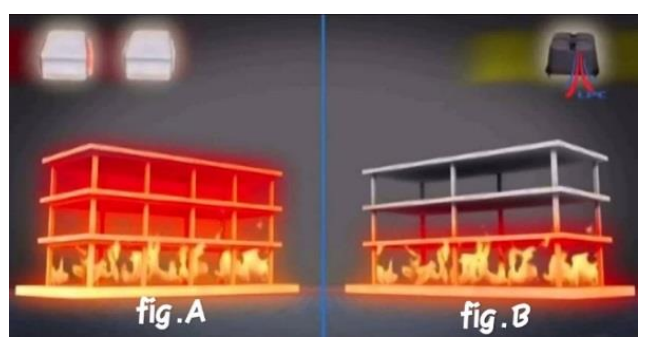

Figure A: Without U-Boot Beton

Figure B: With U-Boot Beton

\section{APPLICATIONS}

> Used in public buildings, hospitals industries, auditoriums, malls, etc.

$>$ Used in raft foundations.

$>$ Used in two way slabs.

\section{BENEFITS OF THIS SYSTEM}

$\checkmark$ Design freedom

$\checkmark$ Down stand beams and bearing walls eliminated

$\checkmark$ Reducing overall costs

$\checkmark$ Reduced dead weight

$\checkmark$ Longer spans between columns

$\checkmark$ Construction is less weather dependent

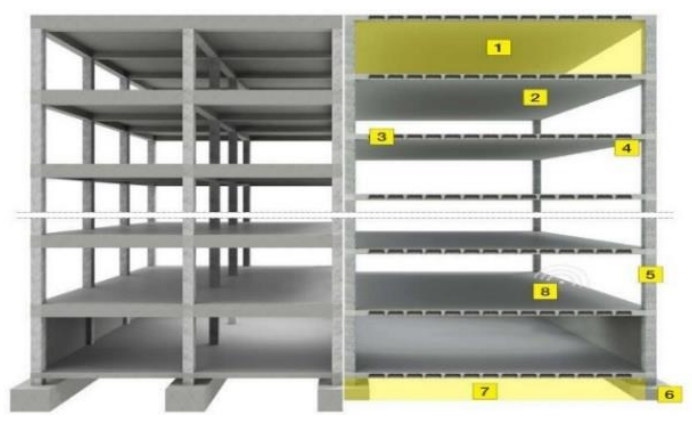

\section{CONCLUSION}

If we want to save more concrete then this technology has to be used, less use of iron in the slabs. Pillars and foundation up to a total of $15 \%$.There are anti-seismic advantages connected to reduced building weight slimmer pillars and foundation, there are low chance of seismic effect on the buildings. Due to the fact, that the structural behaviour of this new kind of monolithic flat slab is the same as for solid slab, excluding slab-edge column connection, we surely can talk appropriateness of use and advantages of the new technology. This technology is very expected in modern construction and perhaps future of civil engineering belongs to this new kind of hollow slab.

\section{REFRENCES}

[1] Dali form group building innovation, creatori, dell iglu.

[2] International Journal of Management, Technology and Engineering (IJMTE), ISSN NO: 2249-7455, Volume 8, Issue VIII, August 2018.

[3] 3.B.Vaignam, Dr.B.S.R.K Prasad Analysis of voided deck slab \& cellular deckslab using Midias Civil.

[4] 4. Yogesh Tambe, PrashantKulkarni, Parametric study of solid slab and voided slab.

\section{BIOGRAPHY}

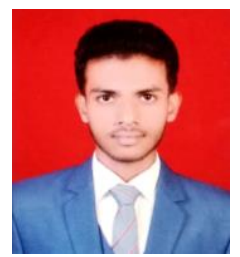

\section{Shoeb Khan Taslim Khan}

Currently pursuing B.E. (Civil Engineering) from Babasaheb Naik College of Engineering, Pusad. 